\title{
Analyzing the Potential Market of Local Color Cosmetics in Indonesia: The Case of an Indonesian Small Medium-Enterprise
}

\author{
Arum Prsasasti \\ University of Muhammadiyah Malang \\ Arumprasasti@gmail.com
}

\begin{abstract}
The aim of this study is to provide a market analysis based upon the case of severalnewly established Indonesian SMEs (Small-Medium Enterprise) in beauty and personal care especially in color cosmetics. The study is conducted with two main objectivesnamely; (1) To determine secondary sources for relevant data on the size and potential scope ofdemand in Indonesian market for local cosmetics, (2)To outline possiblemarket entry strategies fora new company in selected Indonesian regional markets. In achieving thisaim, the study is conducted by using qualitative research, in which the secondary data and primary data collection isutilized. This study is expected todiscover that there is potential market for local cosmetics albeit the fragmented market in Indonesia. However, this study contains certain limitationsbut hopefully it can beaddressed for future research. Nonetheless, this study will create a distinct addition to theknowledge of a Small Medium Entreprise looking to enter beauty and personal care market.
\end{abstract}

Keywords : SME, market entry, beauty and personal care

\section{INTRODUCTION}

Indonesia is one of the biggest countries in the world with 250-million population. The huge amount of its population has created a potential market for beauty and personal care products. According to Euromonitor International, beauty and personal care market size in Indonesia is accounted for Rp 62billions in 2017. This number comprises sales from various products ranging from color cosmetics to bath and shower. The color cosmetic itself contributes to around $30 \%$ of the total sales in beauty and personal care, which indicates a great demand amongst Indonesian consumers. Apart from the international brand that has been established decades ago in Indonesia, new color cosmeticof small-medium enterprise (SME) begins to emerge in Indonesian market. According to Indonesia Government Statistics (2016), SME in Indonesia provides significant contributions towards the economics. Reflecting on this, the development of SME matters to the Indonesian economic development, in which if it is incubated properly, it could become one of the powerful weapons of the country. The combination between one big industry and one SME could give bigger contribution to the national economics.
However, the color cosmetic of SME frequently faces challenges such as strong competitions, lack of qualified human resources, and lack of capital. This aligns with previous research on SME, that in such fragmented market, the competitons will remain tight.Looking at this, this research aims to complete two objectives. First, to find the appropriate data on the size and scope of the color cosmetic in Indonesia. Second, to find the possible market entry strategy for similar SME. The knowledge of potential market is necessary to be obtained by an SME looking into a color cosmetic market. As shown in the previous research by[1]thatargued that SME cannot handle uncertainty due to lack of knowledge. As suchthis research aims to bridge the problems.

\section{METHOD}

The methodology used in this research is qualitative research. In contrast withprimary data, in which the data collected are originated from the researcher at hand according to their purpose, secondary data can be obtained easily and inexpensive, come from a wide range of sources, and usually have high-quality and accurate data collections [2]. Therfore, data collection method being used is secondary data. The methodology is chosen with several considerations. First, the nature of this research is using secondary sources of data.The data are then being analyzed to achieve the aim of this study which is to determine the potential market of color cosmetic in Indonesian market for an Indonesian SME. Therefore, qualitative research is suitable because this method qualifies the researcher to elicit the knowledge from the external documents and the data provided in order to get an insider view from the ground study [3]. Second, this study does not aim to determine the "variables" that are causally related in the market of color cosmetic, but aims to explore the potential market and the possibility of growth in the diverse Indonesian regions. This means that this research is trying to understand the social phenomenon [4]which can be reflected on the fragmented market in Indonesia. Third, this study does not aim to generalize the analysis by implementing this in all SMEs. Since all SMEs have their own unique environments to expand, the analysis is built based on the necessity of the SME being examined. Therefore, the qualitative method is suitable for a case oriented study with this research [5]. Aside from that, this research also includes one in-depth interview to get 
perspectives from the population oriented involved in the day to day business, especially the SMEs owner's perspectives[6].

This study is also mapping articles to create a more systematic analysis towards secondary sources. There is a broad range of information available from formal data sharing that the researcher can obtain such as market report, government publications, academic articles, and news. Unfortunately, some of the sources are not reliable. As such an article mapping is needed in order to find the organization of the secondary sources. First, the data and articles are gauged, then the researcher collects the data based on their level of analysis. Second, the articles are classified into conceptual approaches. The importance of this classification is to help the initial understanding of how diverse the theory being used in developing the perspectives towards the research objectives [7].Table 1 shows how the article is mapped.

Table 1 shows that the article used in this research are 30 in total. The classification has made the secondary sources systematically implemented and beset an important quality for the research.

\section{RESULTS AND DISCUSSION}

\section{The Case of a Color Cosmetic SME in Indonesia}

The ABC company is a newly established company based in Jakarta, Indonesia. The company started the business back in 2016, selling lipstick as its main product. The employees of the company at that moment wereonly 4 people and used online channel as their main channel in selling the products. During the first week of sales, the company was able to sell around 4000 lipsticks which gained total sales of Rp 400 millions. Therefore, within three months of the sales, the company has been able to reach break event [8]. There are plenty of reasons why the business is going so well. First, the owner is one of the most prominent beauty bloggersin Indonesia who is already well-known amongst youth. Second, the owner utilizesher online channelthat targetsmillenials. Millenialsare known as tech-savvy and relatively quick in responding new trends in the market [9]. As such, the response for the products is enormous. Third, it is because of the brand concept. The owner's first step in establishing the business is concepting the product and brand. The next step is finding a make-up company that is in line with her vision, and the third one is producing and selling the products viaonline channel. She mentioned that a brand should have a strong personality attached to it to make it differnet from the competitiors. As Aaker [1] mentioned in his study about brand personality, brand personality has several dimensions, and one of them is excitement which is represented beautifully by this

brand. For instance, the lipstick shades' names are up-to-date and imaginative such as burnt cinnamon and peppermint pie.

According to her, the companyis currently able to sell 1000 lipsticks per day. The company's future plan is to introduce more products aside from lipstick in 2018 to gain more consumers and bring the company to the next level. One of the challenges that the owner states during the interview is that the business is going well yet plenty of newcomers are becoming their strongest opponents. This is shown in the excerpt of the interview as follows:

"...plenty of newcomers are available in the market with similar products"

The challenges may vary in one SME to another SME, as such the challenges can't be generalized for all SMEs in Indonesia. Yet, the fact that one of the most prominent color cosmetic companies, that experiences the competitions, shows that the main challenges from competitors are presents.

\section{The size and potential scope of demand in Indonesian market for local cosmetics}

According to the data from Euromonitor International, Indonesia as one of the largest markets in Asia, possessesgreat potential in the market. The table 1.2 shows the current market size of beauty and personal care in Indonesia.

Table 1. Article Mapping

\begin{tabular}{|c|l|c|c|c|}
\hline No & \multicolumn{1}{|c|}{ Research Objectives } & $\begin{array}{c}\text { Studies } \\
\text { assessing the } \\
\text { numerical data }\end{array}$ & $\begin{array}{c}\text { Studies assessing the } \\
\text { conceptual approaches }\end{array}$ & $\begin{array}{c}\text { Studies assessing } \\
\text { the empirical } \\
\text { approaches }\end{array}$ \\
\hline 1 & $\begin{array}{l}\text { Studies assessing the sizes, } \\
\text { scopes and demands of } \\
\text { color cosmetic }\end{array}$ & 15 & & \\
\hline 2 & $\begin{array}{l}\text { Studies examining the } \\
\text { possible market entry } \\
\text { strategies }\end{array}$ & 5 & & 10 \\
\hline
\end{tabular}


Table 2. Beauty and Personal Care Market Size in Indonesia ( 2012-2016)

\begin{tabular}{cc}
\hline Year & Retail Sales Value \\
\hline 2012 & 37 IDR billion \\
2013 & 43 IDR billion \\
2014 & 50 IDR billion \\
2015 & 58 IDR billion \\
2016 & 62 IDR billion \\
\hline
\end{tabular}

Sources : Euromonitor International, 2016

Table 2 shows that almost $50 \%$ growth from the market size has occurredfrom 2012 to 2016. This indicates that the demand for beauty and personal care in Indonesia is growing siginificantly year by year. The market is very fragmented with many leading brands which are available in the market such as Pond's, Pepsodent, and Sunsilk. The majority of the leading brands are international brands.

Table 3. Color Cosmetic Market Size in Indonesia (20122016)

\begin{tabular}{ll}
\hline Year & Retail Sales Value \\
\hline 2012 & 3,8IDR billions \\
2013 & 4,3 IDR billions \\
2014 & 4,8 IDR billions \\
2015 & 5,2IDR billions \\
2016 & 5,7 IDR billions \\
\hline
\end{tabular}

Source : Euromonitor International, 2016

Reflecting on the Table 1.3, we can infer that the retail sales value for color cosmetic in Indonesiahas grown significantly from 2012 to 2016 . This can be said that the potential market for color cosmetic is great for the color cosmetic in Indonesia. The findings are in line with the reserch found out a(??)

\section{The possible market entry strategies for color cosmetic products in Indonesia}

Having identified promising Indonesian markets, the next part is finding the suitable entry mode for the markets selected. Indonesian consumers tend to be very tech savvy and follow current trends really quickly. According to Kotler and Keller (2009), to enter a new market, a company should consider plenty of things, one of them is a proper distribution channel. Distribution channels can be described as the organization (or set of organizations) participating in the procedure of making a product or service available to be used by individual or business users [10]). The market entry strategies will focus on the distribution channel of the color cosmetics. The distribution channel of products may vary according to the target market. The products should first create a concept to cater the target market better.

It is found out that the current prominent strategy of a newly established brand is through online channel.Online retailing is defined as a newly estaliblished distribution channel. Internet as a direct channel presents a good substitute for traditional distribution channels. Pitt et al. (1999) discussed the effect of internet on distribution strategies thoroughly and joined many other scholars in this orientation [1]. As such, for a newly established company, online retailing could be the fastest way in introducing the products.

\section{CONCLUSION}

This research found that the demand for color cosmetic continues to show prominent growth in Indonesia . At country level, this demand is represented by the number of beauty and personal care sales in total and color cosmetic specifically. Looking at the number of sales, it can be concluded that color cosmetic sales are increasing every year and are forecasted to keep growing in the next few years. It is interesting to see thats

Next, having identified the potential market in Indonesia, it is important to choose the appropriate entry market strategy. Reflecting the current case study, the current state and the limited resources it entails, it is advisable to do market entry strategy by choosing the right distribution channels. Online retailing is feasible for a quick entry to the market and for gaining new brand awareness for Indonesian consumers.

\section{REFERENCES}

[1] Aaker, Jennifer. Dimensions of Brand Personality. Journal of Marketing Research, pp.347. 2010.

[2] Adler, C., 2013. Financial Times. [Online] Available at: http://www.ft.com/cms/s/0/1a54da36e7c811e2babb00144feabdc0.html\#axzz3Wqqo4o9 [Accessed 7 April 2015]. 2013.

[3] Antoni, F., Burgelman, R. \& Meza, P. LVMH in 2004: The Challenges of Strategic Integration. Harvard Business School Case. 2004.

[4] Aulakh, P. S. \& Kotabe, M. An Assesment of Theoretical and Methodological Development in International Marketing: 1980-1990. Journal of International Marketing, 1(2), pp. 5-28. 1993.

[5] Boateng, R. \& Duncombe, R. Mobile Phones and FInancial Services in Developing Countries: A Review of Concepts, Methods, Issues, Evidence, and Future Research Directions. Third World Quarterly, 30(7), pp. 1237-1258. 2009.

[6] Bounds, A. Financial Times. [Online] Available at: http://www.ft.com/cms/s/0/155093b65edc11e1a08700144feabdc0.html\#axzz3Wqqo4o9 [Accessed 7 April 2015]. 2012.

[7] Bryman, A. \& Bell, E. Business Research Methods. 2nd ed. Oxford: Oxford University Press. 2007.

[8] Chesbrough, H. Managing Open Innovation. Industriall Research Institue, pp. 23-26. 2004

[9] Dikova, D., Jaklic, A., Burger, A. \&Kuncic, A. What is Beneficial For First Time SME exporters from a Transition Economy: A Diversified or Focused Export Strategy. Journal of World Business, Volume 739, pp. 1-15. 2015. 